Received: 29 September 2020 Accepted: 14 November 2020

DOI: https://doi.org/10.33182/bc.v10i2.1156

\title{
Annie Ernaux'nun Yalın Tutku romanında kadınlık durumu
}

\begin{abstract}
Ali Tilbe ${ }^{1}$
$\ddot{O} z$

Yalın Tutku'da, (Passion Simple) öteki romanlarında olduğu gibi Ernaux'nun yaşamına yön veren kişisel olaylar öykülenir. Biçemsel açıdan yeniötesi küçürek (fr. minimaliste) anlatının kimi ayırtlarını taşıyan Yalın Tutku, 'sevgiye yabancılaşma, tutkunun kölesi olma ve duygusal şiddete uğrama' gibi izlekleri okura çok çarpıcı biçimde sunan bir özkurmaca benli anlatıdır. Özanlatıcı kadın başkişi, Rus bir diplomata duyduğu yasak aşkın nasıl kösnül bir tutkuya ve sanrlya dönüşüğünü, bu çeşit bir insanca deneyimin herkesi, her an, her yerde bulabileceği olgusunu, tekil birinci kişi ben adılıyla çok açık seçik bir yalınlıkla ve korkusuzca geçmişiyle şimdiyi toplumsal bir süzgeçten geçirerek öyküler. O, aile geçmişiyle de bir hesaplaşmaya girerek, toplumsala boyun eğen kadından, nasıl özgür kadın kimliğine kavuştuğunu anlatarak, geleneksel ataerkil kadın algısını ters yüz etmek ister. Çalışmada, duygusal ve kösnül bir şiddetin sarmalında öz kimliğiyle var olmaya çalışarak kuralcı bir karşı cins baskısına ve toplumsal düzene başkaldıran ve Simone de Beauvoir'ın “Kadın Doğulmaz, Kadın Olunur” savsözünü usa getiren bir kadının tutkulu tutsaklığını izleksel yaklaşımla incelemeyi deneyeceğiz.
\end{abstract}

Açar Sözcükler: Annie Ernaux; Yalın Tutku; kadın; şiddet; özyaşam.

\section{Abstract}

\section{Being women in Annie Ernaux's Simple Passion novel}

In Simple Passion, as in her other novels, the personal events that lead Ernaux's life are narrated. Simple Passion, which carries some of the distinctions of the stylistic postmodernism short story narrative, is an autofictional self-narrative that offers readers such as "alienation to love, being a slave to passion and suffering emotional violence" in a very striking way. The narrative person narrates how her forbidden love for an Eastern stranger turns into a sensual passion and delusion, the phenomenon that such a human experience can find everyone, at any moment, anywhere, by passing the present through a social filter with a very clear simplicity and fearless past with the name of the singular first person "I". This sickly state of passion takes over the narrative person's mind, her life, dragging him toward spiritual and bodily exhaustion. He also wants to enter into a showdown with her family history, tell the woman who has submitted to society how she has gained a free female identity, and reverse the traditional patriarchal perception of women. In the study, we will try to explain the passionate captivity of a woman who refers to Simone de Beauvoir's motto "One Is Not Born, But Rather Becomes, A Woman!" and who defies society by trying to exist with her selfidentity in a spiral of emotional and sensual violence.

Keywords: Annie Ernaux; Simple Passion; women; violence; self-life.

\footnotetext{
${ }^{1}$ Prof. Dr. Ali Tilbe, Namık Kemal Üniversitesi, Fransız Dili ve Edebiyatı Bölümü’nde öğretim üyesidir. Elmek: alitilbe@gmail.com /atilbe@nku.edu.tr/ ORCID ID: https://orcid.org/0000-0003-4634-8822
} 


\section{Annie Ernaux'nun Yalın Tutku romaninda kadinlık durumu}

\section{Giriş}

Annie Ernaux, yirminci yüzyılın ikinci yarısından başlayarak başta Nathalie Sarraute ve Colette olmak üzere, kadın yazarların Fransız yazınında söz sahibi olmaya başladığı dönemde kadın yazınının fitilini ateşleyen ve kadını tüm çıplaklığıyla anlatısına taşıyan öncül yazarlardan birisidir. Ernaux'nun anlatısında işlediği kendi özel ve cinsel yaşamından kesitler içeren oluntular, oldukça sarsıcı ve ses getirici olmuştur. Kuşkusuz kadının yirminci yüzyılın ikinci yarısında kurmacada bu denli özgürce işlenmesi, özellikle İkinci Dünya Savaşı'nın hemen sonrasında Simone de Beauvoir tarafından ele alınan ve daha sonra Hélène Cixous, Luce Irigaray, Pierre Bourdieu ve Julia Kristeva gibi yazar ve kuramcıların evrenini genişlettiği kadın yandaşlığı (fr. féminisme) akımının yarattığı etkiden söz etmek yerinde olacaktır.

$\mathrm{Bu}$ dönemde Beauvoir, dünyada büyük yankı uyandıran, "kadın yandaşlığı, özdekçilik ve tinçözümü” (Gardey, D. \& Meron, M. (2008). P. 153) akımları etkisi altında yazdığı, yeni kadın yandaşlı̆̆ akımının kurucu kuramsal yapıtı olan İkinci Cins (Le Deuxième Sexe, 1949)'de, cinsiyet eşitsizliğini gündeme getirerek kadının eril boyunduruğa başkaldırması ve özgürleşmesi sorununu ele alır. Yazar, kadının konumunu tarihsel, ekinsel ve toplumsal düzlemde tartışarak, ataerkil aile yapısı içinde insansal haklarından yoksun bırakılıp kendi istenci dışında, İnsanlık tarihinin kurucu öznesi erkekler tarafından belirlenen birtakım görevler yüklenerek bedensel ve cinsel bağlamda nasıl bir sömürüye uğradığını tüm açıklığıyla inceler.

1950'li yıllardan sonra dünyada gelişen toplumsal değişimlere koşut olarak, tarih boyunca toplumsal ve siyasal düzeyde söz hakkı olmayan kadının konumu da tartışmaya açılmış ve kadın kendisini özgürce dışa vurma olanağına kavuşmuştur. Bu çok tartışmalı ve çatışmalı geçen toplumsal devinim ve değişim süreci, Avrupa ile Amerika başta olmak üzere, dünyadaki birçok gelişmiş demokratik ülkede Beauvoir'ın yolundan giden, çok sayıda kadın yandaşı (fr. féministe) yazar, kuramcı ve araştırmacının çabasıyla, kadınların artırımsal, siyasal, hukuksal, törel ve toplumsal alanlarda erkeklerle eşit haklar elde etmesiyle sonuçlanmış ve bir kadın hakları savunma akımı olan kadın yandaşlığı gelişmiştir.

Beauvoir, yalnızca felsefesel bir bakış değil aynı zamanda siyasal bir bildirge olan İkinci Cins'in ikinci cildinde yer alan "kadın doğulmaz, olunur"2 savsözünü, "toplumun kadınları nasıl şekillendirdiğini ve domestik hayata içkinleştirdiğini" (Koşar, 2020, s. 96) vurgulamak için kullanmıştır. O, kadınların, kendilerini ekinsel ve toplumsal olarak yeniden tanımlamasının önemime vurgu yaparak, kadın üzerine kurulmuş olan baskı düzeninin ve eril boyunduruğunun aşılmasının, yani tarihsel olarak erkeklere özgü olan aşkınlığa ulaşarak eşit aşkın kişiler olarak özgürce yaşamasının savaşımını vermiştir. Tarihsel olarak alışılagelen kadın algısını tersine çeviren Beauvoir, kadınlık durumuyla ilgili kalıp yargıları parçalamıştır. Erkekler, bedensel üstünlüklerini ve kas güçlerini kullanarak kendi yararlarına bir düzen kurmuşlardır. Kadınlar, bundan böyle yazgılarına boyun eğmeyecek, evlenmek, çocuk doğurmak ve ev işleri yapmaktan oluşan yaşam döngülerini değiştireceklerdir. Kadın-erkek ilişkisini Hegel'in köle-efendi eytişimine benzeten Beauvoir için; "eve ve ev işlerine yönlendirilen kadın, gerçek dünyadan soyutlanmış, içkinliğe terk edilmiştir; evi terk edip kamusal alanda üretici ve etkin olduğu takdirde aşkınlığa erişme imkânına sahip olacaktır. Dünyayı dönüştürme kuvveti, Beauvoir'ın da belirttiği üzere "aşkınlığa" ulaşmakla doğrudan bağıntılıdır” (Koşar, 2020, s. 89). Bu durumda kadın erkekle eşit bir düzeye gelecek ve

${ }^{2}$ Bkz: Beauvoir, S. d. (1993a). Kadın "İkinci Cins" : Genç Kızlık Çă̆ (Cilt 1), (1993b). Evlilik Çăğ (Cilt 2), Bă̆ımsızlı̆̆a Doğru (Cilt 3). (B. Onaran, Çev.) İstanbul: Payel Yayınları 
özgürleşmenin yolunu açacaktır. Beauvoir'ın izinden giden Kristeva da "biz kadın doğarız, ama ben kadın olurum" (Kristeva, 2018, s. 72) diyerek, kadının bir cinsel doyum ve doğurganlık nesnesi olarak gören cinsiyete ilişkin görüşleri tersyüz etmiş ve kadın kimliğinin yeniden kurulması gerektiğinin altını çizmiştir.

Kadın, geleneksel ve törel bağlamda bir nesnedir. Kendisini bu sarmaldan kurtarmak isteyen özgür kadın kimi zaman büyük bir çelişkiye düşerek kendi kadınlık kimliğini de yadsıma durumuna gelebilmektedir. Bu bağlamda Beauvoir (1993b) kadının kadınlık kimliğinden ve cinselliğinden uzaklaşmamasını salık vermektedir:

"Kadından, kadın olabilmek üzere, kendini hem bir nesne, hem de av haline getirmesi, yani yüce, egemen bir varlık olma hakkından vazgeçmesi istenmekte. Erkeğin boyunduruğundan kurtulmuş kadının durumundaki başlıca çelişme budur. Varlığını sakatlamak istemediği için, kadınlık rolünü benimsemeye yanaşmamaktadır; oysa, kadınlığını reddetmek de varlığını sakatlamaktır. Erkek, cinsi erkek olan bir insanî varlıktır; kadın aynı biçimde cinselliğini kabul etmiş insanî bir varlık olduğu an erkeğe eşit, eksiksiz bir birey olabilir ancak. Kadınlığından vazgeçmek, insanlığının bir yanından vazgeçmesi demektir. Kadın düşmanları, kafalı kadınların "kendilerini ihmal ettiklerini" ileri sürerler: oysa bunu onlara kendileri salık vermiştir: bizlerle eşit olmak istiyorsanız, yüzünüzü, gözünüzü, tırnaklarınızı boyamaktan vazgeçin demişlerdir” (s. 117).

Buradan da anlaşılacağı üzere, Beauvoir'ın cinsiyet eşitsizliğini giderme savaşımında, kadınların cinsel kimliğini yok sayarak erkeklere eşit olabilmesi söz konusu olamaz. Eşitlik cinsel yaşamla birlikte her alanda gerçekleşmelidir. İşte tam bu bağlamda Annie Ernaux ayrıcalıklı bir yazar olarak ortaya çıkmaktadır. Yazar bir yandan evliliğine son vererek ataerkil aile yaşamından uzaklaşıp özgürleşirken, bir yandan da bir kadın olarak karşı cins ile yaşadığı tutkulu ve kösnül ilişkisini Yalın Tutku adlı anlatısında tüm açıklığıyla öykülemesi, Fransız yazın tarihi açısından kadın yazınında önemli bir dönemeç olduğu söylenebilir.

Kuşkusuz kurmaca evreninin en önemli kurucu öğelerinden birisi anlatıc1-kişinin kimlik sorunudur. Bu bağlamda en önemli sorgulama nesnesi, yazarın anlatıda kişi olarak var olup olmamasıdır. Kimi yazarlar, kurguladıkları elöyküsel (fr. hétérodiégétique) anlatılarda kişi olarak yer almazlar, her şeyi bilen (fr. narrateur-auteur omniscient) ya da tanık anlatıc1-yazar (fr. narrateurtemoin) olarak başkişinin öyküsünü anlatırlar. Kimi zaman sözcüklerin, öykülemenin arkasına gizlenir, anlatılarındaki bütün göndermeleri dolaylı biçimde gerçekleştirerek ikincil düzeyde bir başkişinin öyküsünü benöyküsel (fr. homodiégétique) tanık anlatıcı olarak öykülerler. Kimi yazarlar da anlatılarında kendilerini görünür kılarlar ve özöyküsel (fr. autodiégétique) anlatılarında anlatıcıkişi (fr. narrateur-personnage) olarak yaşamlarından kesitler sunarlar okura. Okur da, anlatıda hemen onlardan izler ayrımsar ve onların serüvenlerine eşlik etmenin tadına varır. Ernaux son ulamda yer alan yazarlardan birisidir. Bütün anlatılarında yaşamından bir kesit bulmak olasıdır. Romanları kendi yaşamıyla örtüşen birçok öğe ile örülüdür ve yapıtlarının bütünü az ya da çok özyaşamının izlerini taşır, bu nedenle Ernaux'nun anlatısının özkurmaca roman ulamında yer aldığı söylenebilir (Civelek, 2012, s. 124). Yapıtının bütünü, toplumsal(öz)yaşamöyküsünün (fr. autosociobiographie) ürünü olan bir benli anlatı türüdür (Tilbe, 2019, s. 179). Bu çalışmada, Ernaux'nun yaşamı, özelden genele, bireyselden toplumsala kadınlık durumunu ortaya koyar, 


\section{Annie Ernaux'nun Yalın Tutku romanında kadınlık durumu}

varsayımından devinimle yazarın özyaşamında deneyimlediği tutku izleğinden yola çıkarak kadınlık durumunu kadın yandaşlığı yaklaşımı bağlamında ortaya koymayı amaçlamaktayız.

Yazarlık serüvenine kadın hakları tartışmalarının sürüp gittiği yirminci yüzyılın ikinci yarısında başlayan ve orta sınıf bir aileden gelerek eğitimi ve yaptığı evlilikle sınıf atlayan Annie Ernaux, yaşamı boyunca kadın hakları savunuculuğu yaparak kadının özgürleşmesi için çaba harcamış bir savaşçıdır. Bu uğurda verdiği savaşım sonunda, uzun yıllar süren evliliğine son vermiş ve kişisel özgürleşme yolunu seçmiştir. Yazara göre; bir ömür boyu ölene kadar sürecek güvenli bir evlilik yaşamak olası değildir (Magali, 1993). Kadın yandaşlığı kuramında söz edildiği gibi, kadınların çalışma yaşamının dışında kalarak ev işleri ve aile sorumluluklarıyla sınırlı bir yazgıya boyun eğmelerini reddetmektedir. Onun yaşamının, yirminci yüzyıl Fransız toplumu içinde kadının konumunun anlaşılması bağlamında bir örnek oluşturduğu söylenilebilir.

1974 y1lında Les Armoires Vides (Boş Dolaplar) adlı romanıla yazma serüvenine başlayan çağdaş Fransız kadın yazarlardan Annie Ernaux, Bir Adam (La Place), Bir Kadın (Une Femme) ve Yalın Tutku (Passion simple) Yıllar (Les Annnées) adlı romanları ile özyaşamından kesitler sunar. İlk romanı Boş Dolaplar (1974)'da bir işçi çocuğunun anılarını öyküleyerek, toplumsal sınıf farklılıklarını dışa vurur (Tilbe, 2019, s. 186). İzleyen yapıtlarında da özyaşamından örüntülere yönelir. Ben(öz)öyküsel anlatılarının genelinde kadınlık durumunu değişik görünümlerini ele alan Ernaux, cinsellik, ölüm, çocuk aldırma (kürtaj), toplumsal ezilmişlik, yabancılaşma, ebeveynlerden utanma, kadının aşağılanması ve özgürleşmesi gibi izlekleri öne çıkarır.

“La Place ve La Honte'da babasını (erkek kimliğini), Ce qu'ils disent ou rien'de kendi gençlik dönemini (kadın kimliğini), La Femme gelée'de evliliğini (kadın-erkek kimliğini), L'évenement'da kürtajını (kadın kimliğini), Je ne suis pas sortie de ma nuit'de annesinin Alzheimer hastalığını (kadın kimliğini), Une Femme'da annesinin ölümünü (kadın kimliğini) ve L'usage de la Photo'da kanser oluşunu ve yaşadığ 1 tutkulu aşkı (kadın-erkek kimliğini), özyaşamöyküsel veriler kullanarak kaleme alır. Böylelikle, yapıtlarının arka planında kadın ve erkek kimliklerine yüklediği anlamı sorgulaması söz konusudur" (Sözmez Öz, 2015, s. 240).

Yazar, yeni toplumsal yapı içinde benin kayboluştan kurtulma çabasına girişerek, ben ve öteki ile toplumsal ve kişisel arasında bir yerde konumlanır. Okur, anlatıcı ben ile kendisini özdeşleştirmekten alamaz. Böylelikle Ernaux'nun öyküsünün, herkesin ortak öyküsü olabileceği çıkarımı yapılabilir. Ernaux için söylem, gerçekte okura korku vermek, onda utanç ve kıskançlık duyguları uyandırmak değil, tersine sözcüğe düşünülemez olan anlamları yüklemek, dışarıda bir şey bırakmamak anlamına gelir.

Yirminci yüzyılda kadın yazarlar arasında özellikle Ernaux'nun anlatısı, değiştirici niteliğiyle geniş bir evrimin parçası konumundadır. 1970'li yıllara kadar kadın söylemi sürekli yasaklarla karşılaşırken, 1968 Mayıs eylemleri sonrasında Cixous, Kristeva gibi kadın yazarlar bedenlerini anlatılarına taşıyarak ağır cinsellik içeren romanlar yazmışlardır: "Tüm bu kadın yazarların ortak noktası, kösnül (fr. érotique) olanı erkekler ve kadınlar arasındaki ilişkiler bağlamına sağlam bir şekilde yerleştirme eğilimidir" (Romanowski, 2002, s. 105). Ernaux'nun içinde yer aldığ 1 kadın yazarlar, baskıcı ataerkil toplumsal yapıya karşı koymak için cinsel yaşamlarını korkusuzca ve özgürce anlatıya taşıyarak eleştirel bir yaklaşım ortaya koymuşlardır. 
Ernaux, Yalın Tutku'da her ne kadar özgür kadın imgesinden uzak, kadın yandaşlı̆̆ına ters düşen tutkusunun tutsağı olmuş bir kadın görüntüsü ele alsa da, sonuçta bir kadın tarafindan yaşanabilecek olan insansal bir duyguyu okurla paylaştı̆̆ söylenebilir.

\section{Tutkunun Olanaksızlığı}

Yalın Tutku, her şeyden önce bir aldatma romanıdır. Her ne kadar eşinden ayrılmış bir kadının tutkuyla yaşadığı bir öykü söz konusu olsa da, anlatının erkek eyleyeni A harfiyle çağrılan kişi, evli bir Rus diplomattır. Bir yanda bir kadının böyle ilişkiyi yaşamayı kabul etmiş olması, öte yandan da evli bir erkeğin eşini aldatmakta bir engel görmemesi, gerçekte anamalcı toplumlarda yaşanan toplumsal çöküntüye sarsıcı bir göndermedir. Ernaux, romanlarının genelinde buna benzer toplumsal sorunları gözü peklikle ele almış ve düşüşte olan anamalcı törel değerleri kendi yaşamından yola çıkarak toplumsal bağlama taşımıştır.

Yalın Tutku, büyük bir içtenlikle yazılmış önemli bir deneyimin paylaşıldığı, içtenlik ve doğruluk izlenimi uyandıran bir benli anlatıdır. Paule Constant'a göre, "Yalın Tutku, romanda, Yabancı'nın kendi dönemindeki kadar önemli bir dönüşüm sağlar, öyle ki, böyle bir kitabın yayınlanmasından sonra, birdenbire gözden düşen bütün bir kadın yazını, bundan sonra eskiden yazıldığı gibi yazılamayacaktır" (Tondeur, 1996, s. 109). Burada kadın yazınının durumu tüm açıklığıyla okura sunulmaktadır. "Kadın yazarlar, pembe dizi romanlar yazma endişesiyle, cinselliği çok öne çıkarmadan yazmaktadırlar. Ancak son yıllarda başta Annie Ernaux olmak üzere Alina Reyes, Benoite Groult gibi çok sayıda kadın yazar, kendi deneyimlerinden yola çıkarak dokunmaktan korkulan konularda romanlar yazmaktadırlar" (Tilbe, 2019, s. 190). Annie Ernaux, "kadını ikinci sınıf vatandaş konumundan çıkararak toplumun ona yüklediği sorumlulukları da omuzlarına alarak özgürlüğünü elde etmeyi başarmış bir kadın yazardır” (Sözmez Öz, 2015, s. 248).

Sayın, romanda kadınlık durumunu en yalın biçimde ortaya koyan başlıca üç göstergeden söz eder.

"Bunlardan en önemlisi, tüm ortak değerlere aykırı olarak evli bir erkekle birlikte olması, ikincisi yanlış olduğunu bilerek yasak ilişkisini çocuklarına yeğlemesi ve son olarak yazdıklarının yayınlandıktan sonra okunacağının ve okur tarafından suçlanacağının farkında olup, romanını yazmaya devam etmesidir. Her üç eylemde de anlatıcı kahraman bir seçim yapar ve sonuçlarını kabullenmeyi göze alır. Varoluşunu kanıtlayan üç seçimden birincisi olumlu sonuçlanırken diğer ikisi anlatıcı-kadın kahramanı pişmanlığa götürür" (Sayın, 2019, s. 166).

Roman, toplumsal olarak yasak kabul edilen birçok olguyu tartışmaya açmaktadır. Daha başlangıçta üzgöreçte şifreli bir kanalda oynayan cinsel içerikli bir film ilk anlatıyla ilgili önsel bilgi vermektedir okura. Kuşkusuz yazarın önemli göndergelerinden birisi, bu çağda cinselliğin "şimdi bir el sıkışmaya bakmak kadar kolay" (Ernaux, 1992, s. 11) olduğunu gözler önüne sermesidir. Yalın Tutku, hiçbir biçimde salt açık saçık bir anlatı olarak değerlendirmek yerine, "kadının şehvetinin sınırlarını sorgulayan" (Tilbe, 2019, 190) bir roman olarak okumak daha uygun olacaktır.

Her ne kadar temel hak ve özgürlükler konusunda göreli bir özgürlüğe sahip olsa da, geçen yüzyılın sonlarında Katolik Fransa'da, bir kadın yazarın cinsel deneyimlerini öyküleyen bir roman yazmaya girişmesi gözü peklik gerektirecek bir durumdur. Ernaux bir söyleşisinde bu konuda şunları dile getirir: 
"Onların hoşuna giden şey, bir kadının onlar gibi arzularının sonucunu üstlenmesidir, sonuçta hiçbir şey istemeyen bir kadın var. (...) Denilebilir ki, bu tutkuyu üstlenerek ve ondan utanmadan, hâlbuki biz Fransızlar düşüncede çok fazlaca cinselliğin kötü bir şey olduğunu öğrendik, onlara bir çeşit özgürlük verdim, yani vanaları açtım” (Magali, 1993).

Tekil birinci kişide özöyküsel anlatıcı tarafından öykülenen anlatıda, yazar gerçekçi bir söylem kullanır. "Kendisine özgü yalınlıkla yaşamından bir kesit sunar. Nerede ve ne zaman durması gerektiğini bilen, okurun duygularını kötüye kullanmayan bir anlatıcı söz konusudur. Benzeşik oluntuların sürekli yinelendiği, öykünün çok hızlı ilerlemediği görülür" (Tilbe, 2019, s.183). Romanda baskın olan bekleme ve sevişme oluntuları, sıklıkla yinelenen deyimler, tırnak ve ayraç içinde verilen açıklama tümceleri, sayfa düzeninde yapılan ilginç görünümler küçürek romanları anımsatır.

Yazar, başlangıçta romanına Sıradan Tutku (Passion Ordinaire) adını vermeyi tasarlar, ancak Romy Schneidre'in Yalın Öykü (Histoire Simple) adlı filmini izlemesinin ardından, yapıtın adını Yalın Tutku (Passion Simple) olarak değiştirir (Tondeur, 1996, s. 121). "Adsız başkişinin adının A harfi olarak belirlenmesine gelince, abc'nin ilk harfi olması nedeniyle onu A diye çağırır. Çünkü A harfi aynı zamanda kendi adının da ilk harfidir. Bunun yanında Fransızca aşk (fr. amour), sevgili (fr. amant) ya da ortak ad (fr. anonyme) sözcükleri de A harfi ile başlar. Yazar, bir çeşit sözcük oyunu ile anlatıda sessel bir uyum yakalamak istemektedir. Bunun yanında "yalın tutku" adlandırması Fransızca geçmiş zamanı da (fr. passé simple) çağrıştırır" (Tilbe, 2019, s. 183). Buradan da yaşanmış olanın anlatılması erek edinilir. Bu, yitirilmiş bir anın, yaşanmış bir tutkunun izini süren, yazıyla onu ölümsüzleştirmek isteyen bir anlatıdır'

Romanının kadın-başkişi saplantılı bir biçimde, okurun hakkında çok az bilgiye iye olduğu Rus sevgilisine takıntılıdır. "A" olarak adlandırılan Rus sevgilinin diplomat, evli, iyi tasarımcıların kıyafetlerini ve viskiyi seven ve belli belirsiz bir biçimde Alain Delon'a benzeyen (Ernaux, 1992, s. 37) bilgiler dışında kimliği üzerine daha ayrıntılı bilgi verilmemektedir. Anlatıda çok yer almamasına karşın, anlatıcı-kişi onu genellikle düşünde, imgesinde, düşleminde ve düşüncesinde yaşatır. “"A"nın yazarın kafasındaki yeri daimidir fakat bir o kadar da gerçekdışı, hayali bir özelliği vardır. "A"nın varlığı sadece bir hayalettir" (Akmanoğlu, 2015, s. 36-37).

Ernaux, gerçek yaşamında deneyimlediği sayısız aşk acısını, bekleme ve beklentilerini, tutkuyla bağlanmalarını ve düş kırıklıklarını Yalın Tutku' da somutlaştırarak, A ile yaşadığı sorunsal aşk ilişkisi ile dışsallaştırır. Geleneksel bir ailede yaralı bir tinle yetiştirilmiş olması, daha genç bir kız iken çocuk aldırmak zorunda kalması, her ne kadar toplumca onanmış bir yaşam sürme istenci ortaya koysa da mutsuz bir evliliği uzun bir süre sürdürmek zorunda kalması, ebeveynleri ve çevresi ile sorunlar yaşamasına yol açmıştır. Bu yıkımlar kuşkusuz yazarın roman evrenini çevreleyen örüntülerdir. Özanlatıcı (fr. autonarrateur) kişinin duyumsadığı düş kırıklığı Louis Aragon'un "mutlu aşk yoktur" sözünü anımsatır. Mutluluk, özanlatıcı için beklenen ancak gelmeyen bir düşsel ve düşlemsel bir olgudur.

Roman geriye dönük olarak geçmiş zaman kipiyle öykülenen açılamalarla başlar. Daha sonra kendi öyküsünü anlatan özöyküsel anlatıcı, "bu yaz Canal Plus'de ilk kez bir porno film izledim" (Ernaux, 1992, s. 9) tümcesinde öykü süresine ilişkin bilgi verir. Daha sonra da "geçen yılın Eylül ayından bu yana artık bir erkeği beklemekten başka bir şey yapmadım. Bana telefon etsin evime gelsin istedim" (s. 11) diyerek öykü süresinin yaklaşık bir yıla uzandığını imler. Öykü süresi ile 
öyküleme süresi arasında yaklaşı üç yıllık bir uzaklık bulunmaktadır. "Anlatıcı '1988 Eylül'ünden 1989 Kasım'ına' (Lebrun, 2001) kadar başından geçenleri öykülemektedir. 1991'in 20 Ocağında Ernaux, Rus diplomatla son kez karşılaşır; "Geçen mayıs ayında yazmayı bıraktığım anla, şimdi, 6 Şubat 91 arasında koalisyon devletleri Irak'la öngörülen savaşı başlattılar” (Ernaux, 1992, s. 53), "Savaşın ilk Pazar günü, akşam telefon çaldı. A'nın sesi. Birkaç saniye dehşete kapıldım" (s. 54), "Bizim öykümüzün zamanı içinde, sadece bir tarih bu, 20 Ocak" (s. 55). 1 yıl sonra 1992 Ocak ayında Yalın Tutku yayınlanır. Demek ki, romanı yazma süresi yaklaşık 3 yılı kapsamaktadır" (Tilbe, 2019, s. 194).

Yazar, "tüm bir yıl boyunca yaşamımda atıl oldum” (Lebrun, 2001) diyerek tutku karşısındaki edilgenliğini kesinler. Yavaş yavaş konunun özüne girerek, geçmişte yaşananları dışsallaştırmayı ve bu tutkunun gerçekliğini romanlaştırarak yakalamayı ister. Ancak yazma biçiminin ne olduğu konusunda kararsızdır;

"Tüm geçen zamanda tutkumu romanesk bir içimde yaşıyorum izlenimi içindeyim, ama şimdi onu hangi biçimde yazdığımı bilmiyorum; bir şeyi kanıtlama biçiminde mi, hatta kadın dergilerinde görüldüğ̈u gibi mi, bir sır verme biçiminde mi, bir bildiri ya da bir tutanak ya da hatta bir metin yorumlama biçiminde mi, bilmiyorum" (Ernaux, 1992, s. 23). "Çoğu zaman bu tutkuyu bir kitap yazıyormuşçasına yaşadığımı sanıyordum. Her aşamada aynı başarılı olma zorunluluğu, tüm ayrıntılarda aynı kaygı" (s. 18).

Anlatıcı-kadın, yaşadığ 1 tutkuyu bir romancının roman yazma serüvenine benzetmekte ve romanın kurmaca niteliği ile yaşadıkları arasında bir ilinti kurmaya çaba göstermektedir derken tutkunun yazıya dökülmesi, kurmaca roman evreninin kuruluşu gibidir.

Öte yandan, bu anlatıda yazar, ekinsel bir açıklama yapma ereği gütmez, tüm toplumsal, ekinsel ve tinsel yargıların ötesinde, gösterişsiz bir biçimde yaşadıklarını üstkurmaca (fr. métafiction) uygulayımıyla okurla paylaşmak ister.

"Benim tutkumun kökenine gelince, bunu, bir psikanalistin ortaya çıkaracağı ne uzak ne de yakın bir yaşam öyküsünde ne de çocukluğumdan bu yana beni etkileyen, duygu ile kültürel örneklerde (...) aramak niyetindeyim. Tutkumu açıklamak değil -bu, onu bir yanılg1 ya da bir kargaşa gibi düşünmek olur ki bundan aklanmak gerekir-, sadece sergilemek istiyorum" (s. 24).

Tutkunun tutsağı olan anlatıcı-kadın bu sıra dışı serüveni süredizimsel olarak anlatmaz. Öyle ki "varlık ile yokluk arasında yaşanan ikili bir süresel düzlem söz konusudur" (Tilbe, 2019, s. 200). A, roman içinde bir özne değil, tam tersine kadının cinsel arzularını giderecek bir araçtır. Onun ile yaşananlar hakkından okurun törel bir yargıya varmasının yerine, o dönemdeki kadının toplumsal koşullarını anlamasını bekler. Bu yaşananlar sanki takvim süresinin dışında yaşanmış gibidir.

Anlatıda süre askıya alınmış gibi beklenti içinde akarken, geçen her an, kendisinin var olmasına aracılık eden bu serüvenin sonuna yaklaşması düşüncesi, anlatı başkişisi için her zamankinden daha sarsıcı olmaya başlar. Onun için geçen her süre yaşanacaklardan çalınan bir zaman dilimidir. Ancak bu beklenti ve bekleme eylemi, ayrımına varmakta zorlanan kadında bir saplantıya dönüşecek ve bir çeşit tutku kurbanına dönüştürecektir.

Anlatı içinde zamanın durağanlığına eşlik eden ikinci yerlem kuşkusuz uzamdır. Anlatıda 
buluşmalar için özel olarak hazırlanmış olan çiçekler, temiz çarşaflar, havlu bornozlar ve küçük yiyeceklerle dolu bir Paris banliyö evi betimlenmektedir. Anlatıcının var olmadı zamanlarda bu ev, yazgı kurbanı kadın için devinimsiz ve esenliksiz bir uzama dönüşmektedir. Bütün gün içinde kapalı bir biçimde beklediği evin odasındaki telefon, özanlatıcıyı dış dünyaya ve özellikle A'ya bağlayan yaşamsal bir araçtır. Kişisel işlerini bile yapmak için telefonun başından ayrılır ve yalnızca işe gitmek için dışarı çıkar.

"Benim için bir tek gerçek vardı, o da bir randevu saptamak üzere hep bir sonraki telefonun çalmasıydı. Mesleksel zorunluluklarımın dışında -A bunların saatlerini biliyordu- ben yokken telefon eder de kaçırırım korkusuyla, evden olduğunca az çıkıyordum" (Ernaux, 1992, s. 13).

Görüldüğü gibi, ev bu yasak aşkın yaşandığı tek uzam olarak anlatıda önemli bir işlev üstlenmektedir. Sıkıntılı anlar, A’nın gelişiyle kısa süreler için de olsa, yerini kısa mutlu ve esenlikli zamanlara bırakır. Anlatıcı-kişi için ev, tutkunun zirve yaptı̆̆ı, doyumsuz zevklerin yaşandığı bir sığınak gibidir. Beklemeyle geçen acılı zamanlar, kısa karşılaşmalarla göreceli mutluluklara dönüşür. $\mathrm{Bu}$ anlarda saat durmuş ve süre donmuş gibidir. A'nın varlığıyla kendinden geçen kadın için bu anların dışındaki her şey boş ve yararsızdır. Kadın duygusal ve tinsel olarak yokluk içinde varlık yaşamakta olduğu sanrısına kapılmaktadır.

"Bu işte benim için kronoloji yoktu; sadece varlı̆ğ ya da yokluğu biliyordum" (s. 23).

"Kimi zaman, kendi kendime, belki bütün gününü bir saniye bile beni düşünmeden, sanki ben var değilmişim gibi geçiriyor diyordum" (s. 29).

Anlatı başkişisi, yaşamış olduğu bu yasak ilişkide son derece titiz ve özenlidir. A ile karşılaşmadan önce yatağa yeni çarşaflar takar ve odayı güzel kokulu çiçeklerle bezer. A, buzlu Whisky, meyve ve atıştırmalıklar sunumu tamamlayan öğelerdir. Bunun yanında görüşmelerini kendi çalışma izlencesine göre ayarlamaya çalışmasından ötürü, bu sınırlı zaman kesitlerinde, A'nın eşinin bu ilişkiyi anlamaması için elinden geleni yapmaktadır.

"Giysilerinin üstünde benden hiçbir iz kalmamasına dikkat ediyor, vücudunda da iz bırakmıyordum. Bunları karısı ile arasında herhangi bir olay çıkmasını önlemek isteğiyle olduğu kadar, beni bırakmasına neden olabilecek bir kin duymaması isteğiyle yapiyordum" (s. 28).

Anlatı başkişisi, bir yandan evlilik ve toplumsal yaşamın kimi olumsuz yanlarından söz ederek kadının özgürleşmesini salık verirken, kendisini bir tutkunun tutsağı yapması, öztutumuyla çelişkin görünmektedir.

$\mathrm{Bu}$ çelişkili gibi görünen durum Ernaux için olağan karşılanmaktadır. Ona göre; "tutku, yalnızca varsılların bir ayrıcalığı olamaz" (Magali, 1993). Tutku, herkesçe yaşanması gereken bir özel ve eşsiz bir duygudur ve bu çeşit ilişkiler kişilerin kendilerini tanımalarına ve sınırlarını belirlemelerine yardım edecektir. Bu bir anlamda ataerkil bakış açıcıyla erkeklere ayrılan bir ayrıcalıktan kadın olarak yararlanma ve seçme ve eyleme geçirme istencini ortaya koyma özgürlüğüdür onun için.

"Onun sayesinde, beni bu başka kadından ayıran sınıra yaklaştım, kimi zaman bu sınırı aşmayı düşünecek kadar. Zamanımı bütün bedenimle başka türlü harcadım. İnsanın neler yapabileceğini, hem de her şeyi yapabileceğini keşfettim. Yüce ya da bıktırıcı istekler, onursuzluk, kendimde olmadıkça başkalarında saçma bulduğum inançlar ve 
davranışlar. Haberi olmadan o beni dünyaya daha çok bağladı" (Ernaux, 1992, s. 5657).

Çok katı kurallarla yetiştirilen Ernaux, evreni boyun eğen bir kadın olarak algıladığından, ilk gençlik yıllarında bir sevgili edinme düşüncesinden uzaktır. Alain Delon'a benzeyen bu doğulu adam A ile yaşadığı ilişki, bir anlamda gençlik yıllarında kaçırdıklarının bir sonradan yaşaması anlamına gelecektir. "Ernaux, A aracılığıyla bu iç sürgünden kurtulur. İşçi bir taşra ailede yetişen Ernaux, eğitimi sırasında tanıdığ 1 yeni kenter yaşam biçimiyle büyük bir çelişki yaşar. Aynı çelişkiye geldiği toplumu hiç tanımadığ $\mathrm{A}$ ile yaşadığı ilişkide tanık olur (Tilbe, 2019, s. 207).

Büyük bir tinsel bunalım yaşayan ve tutkunun esiri olan özanlatıcı, bir yandan özgerçekliğiyle yüzleşirken, öte yandan da kendisini büyük bir açmaza ve katlanılamaz bir duruma sokmaktadır. $\mathrm{Bu}$ yüzleşmenin sonunda, bilinçaltının dolambaçlarında gizlenmiş ve unutulmuş karanlık uğrakları aydınlanacak ve böylelikle tutku evrensel bir anlam kazanacaktır.

"Bu zorluklar üstelik bir bekleyiş ve istek kaynağıydı. Beni hep makinesinin nasıl çalışacağı kestirilemeyen telefon kulübelerinden aradığı için, alıcımı kaldırdığımda çoğunlukla ses gelmiyordu. Zamanla, bu "yanlış" telefonun "doğru" olandan en çok on beş dakika önce geldiğini öğrendim. Bu süre içinde çalışan bir makine bulmaya çabalıyordu. O ses gelmeyen ilk telefon onun sesinin müjdecisiydi, kesin bir (ender) mutluluk vaadiydi ve adımı söyleyeceği, "görüşebilir miyiz?" diye soracağı ikinci telefon gelip de o en mutlu anlardan biri olacak ana kadar geçecek süreyi haber veriyordu" (s. 28-29).

Yazar, başından geçen bu dokunaklı deneyimi okurla paylaşırken üstkurmaca uygulayımıyla ona seslenir ve onu yazma serüvenine ortak eder. Okurla geçeklik ve içtenlik sözleşmesi yaparak, yaşanan bu duygunun herkes tarafindan anlaşılabileceğini umut eder.

"Akşamları televizyonun karşısında, acaba o da benim gibi aynı programı mı ya da aynı filmi mi izliyor, özellikle konu aşk $\mathrm{ml}$, erotizm mi, senaryonun bizim durumumuzla ilgisi var mı diye kendi kendime soruyor, Yandaki Kadın adlı filmi kişilerin yerine bizi koyarak izlediğini düşünüyordum. Bana bu filmi gerçekten gördügünü söylese, bunu o akşam bizim için seçtiğini ve ekrana aktarılan öykümüzün ona daha güzel, herhalde daha haklı görünmesi gerektiğini sanmak eğiliminde oluyordum. Doğal olarak, sinemada evlilik dışı tüm aşklar her zaman kötü sonuçlandığı için, tersine, ilişkimizin ona tehlikeli gibi geleceği düşüncesini hemen bırakıyordum" (s. 29).

Yalın Tutku, daha önce Donmuş Kadın'da “iş, eş ve annelik üçgeninde köleleşen kadının, özgürlüğe kavuşmasının bir tutanağıdır. Bu anlatı, Ernaux'nun bir çeşit kimlik arayışının öyküsüdür" (Tilbe, 2019, s. 207). Yvetot'da 2 çocukla 18 yıl boyunca yürüttüğü evliliği sırasında yaşadıkları, başından geçen çocuk aldırma olayı ve uğradığı baskılar onun anlatı evreninin yapı taşlarını oluşturur. Annesinin ölümünden sonra göreceli bir özgürlük kazanmasını; "annem yaşarken, daha kısıtlıydım" (Tondeur, 1996, s. 122, Romanowski, 2002, s. 99) biçiminde dışa vurur. Annesinin cinsellik başta olmak üzere birçok konuda katı tutumuna karşı babası sevecen ve yumuşaktır ona karşı. "Özyaşamının kökleri üzerine bir araştırma ürünü” (Tondeur, 1996, s. 123) olan Ernaux'nun yazısı, onun toplumsala karşı başkaldırı ve varoluş aracıdır. Ernaux; "çocukken benim için lüks, kürk mantolar, uzun giysiler, deniz kıyısında villalardı. Daha sonra, bunun bir aydın 
yaşamı sürmek olduğunu sandım. Şimdi bana öyle geliyor ki lüks, aynı zamanda, bir erkeğe ya da bir kadına olan tutkuyu yaşayabilmektir" (1992, s. 57) diyerek insan yaşamındaki dönüşümlere vurgu yapar.

\section{Sonuç yerine}

Yalın Tutku, yirminci yüzyılda kadın yandaşlığı akımının öne çıktığı dönemde kadınlık durumunu en yasaklı konulardan devinimle öyküleyen bir kadın romanıdır. Özellikle, yabancılaşmış ve kutsallığını yitirmiş olan bu yüzyıl insanları arasında kadın olarak var olmaya çalışmak daha da zor bir olgudur. Öyle ki kadın, özgürlükten yoksun bırakılmış, büyük cinsiyet ayrımcılıklarına uğramış ve doğuştan gelen insan haklarını kullanmasına bile uzun bir tarihsel süreçte izin verilmemiştir. Bu yüzyıl bu anlamda da bir dönüşüm çağı olarak belirmiş, evrenselleşen yeni dizge içinde kadınların konumu da verilen büyük savaşımlar sonucunda yeniden belirlenmiştir. Ernaux'nun anlatı evreni de bu değişim ve dönüşümün tanıklık etmektedir. Kadın anlatıcının böyle bir dönemde yaşadığ bu cinsellik deneyiminin anlatıda böylesine bir kurguyla okurla buluşması, Ernaux açısından kurulu düzene bir başkaldırı ve meydan okumadır.

Ernaux, romanlarının genelinde kişisel deneyimlerinden yola çıkarak, evrensel bir ortak toplumsal öykü oluşturmak ister. Bu bağlamda yazarın anlatı evreni toplumsal bir özyaşamöyküsü olarak değerlendirilebilir. Yirminci yüzyılda halen kadın haklarının çiğnendiği bir çağda, yazısı aracılığıyla insanlığa verdiği bu kadın özgürleşmesi çığlı̆̆ı, hala günümüzde yazmayı sürdürdüğü yeni anlatılarında çınlamaktadır. Orta sınıf bir Fransız ailesinde doğup, bu sınıfın kadınlarının yaşadığı bütün bunalım ve zorlukları deneyimlemiş birisi olarak anlatılarında özanlatıcı anlatı kişisi olarak var olması ve okura buradan korkusuzca seslenerek, ezilen kadınların her çeşit hakkını dile getirmesi onun aydın bir yazar olma bilinciyle açılanabilir. Tüm yapıtlarında yaşamdan esinlenerek gerçekliğe ilişkin gözlem ve sorgulamalarını yansıtarak özgün bir güzelduyusal anlayış geliştirir. Yalın Tutku, insanlar tarafindan yaşanması en olası olan aşk ve tutku izleklerini en çarpıcı biçimde betimleyen ve kadının toplumsal konumu ne olursa olsun tutkunun ve yasak aşkın insanları nasıl ele geçirebileceğini capcanlı kılan özgün bir benli kadın anlatılarından birisidir.

\section{Kaynakça}

Akmanoğlu, Z. N. (2015). Annie Ernaux’nun Bir Kadın ve Bir Adam Adlı Yapıtlarında Metinlerarasılık ve Anne-Kız İlişkisi. (Yayınlanmamış Yüksek Lisans Tezi). İstanbul Üniversitesi, İstanbul.

Aksoy Alp, E. (2012). L'Enonciation et la Polyphonie dans l'Euvre d'Annie Ernaux. (Yaymlanmamış Doktora Tezi). Hacettepe Üniversitesi. Ankara.

Barthes, R. (1977). Fragments d'un discours amoureux, Paris: Seuil.

Beauvoir, S. (1993b). Kadın "İkinci Cins" : Genç Kızlık Çağı (Cilt 1). (B. Onaran, Çev.) İstanbul: Payel Yayınları.

Beauvoir, S. (2010). Kadın "İkinci Cins": Evlilik Çağı (Cilt 2). (B. Onaran, Çev.) İstanbul: Payel Yayınevi. Beauvoir, S. (1993a). Kadın "İkinci Cins" : Bağımsızlığa Doğru (Cilt 3). (B. Onaran, Çev.). İstanbul: Payel Yayınları.

Bourdieu, P. (2016). Eril Tahakküm. (B. Yılmaz, Çev.). İstanbul: Bağlam Yayıncılık.

Civelek, K. (2012). Une Passion Transformée en une œuvre littéraire Passion Simple d'Annie Ernaux. Interstudia, 12, 122-130.

Ernaux, A. (1992). Yalın Tutku. (Y. Avunç, Çev). İstanbul: Can Yayınları.

Foucault, M. (2007). Cinselliğin Tarihi. (H. U. Tanrı̈̈ver, Çev.). İstanbul: Ayrıntı Yayınları.

Gardey, D. \& Meron, M. (2008). Re-lire Le Deuxième Sexe de Simone de Beauvoir. Travail Genre et Sociétés, 2, 151-153. 
Gasparini, P. (2007). Annie Ernaux, de Se perdre à Passion simple. Jean-Louis Jeannelle et Catherine Viollet (Ed.). Dans Genèse et autofiction, “Au cœur des textes”. (pp. 149-173). Louvain-la-Neuve: BruylantAcademia.

Irigaray, L. (2006). Ben Sen Biz: Farklılık Kültürüne Doğru. (S. Büyükdüvenci, \& N. Tutal, Çev.). Ankara: İmge Kitabevi.

Jauffret, M. (1993). Ernaux; la passion est extraconjugale à $100 \%$. Erişim adresi: http://www.humanite.fr/1993-01-26_Articles_-Annie-Ernaux-la-passion-est-extraconjugale-a-100.

Kojève, A. (2001). Hegel Felsefesine Gïriş. (S. Silav, Çev.). İstanbul: Yapı Kredi Yayınları.

Kristeva, J. (2018). Simone de Beauvoir Aramızda. (Ö. Berksoy, Çev.). İstanbul: Sel Yayıncılık.

Lebrun, J-C. (2001). La chronique littéraire. Erişim adresi: http://www.humanite.fr/2001-02-15_Cultures_Au-fil-des-pages-La-chronique-litteraire-de-Jean-Claude-Lebrun.

Papillon, J. (2009). Ernaux ou la traversée des genres: entre Passion simple et Se perdre. Université de Toronto. Erişim adresi: https://brocku.ca/cfra/voixplurielles06-01/index.html.

Romanowski, S. (Fall 2002). Passion simple d'Annie Ernaux: le trajet d'une feministe. French Forum, University of Pennsylvania Pres, 27 (3), 99-114.

Sayın, M. (2019). Annie Ernaux’nun Yalın Tutku ve Philippe Sollers'in Sabit Tutku Adlı Romanlarında “Tutku”nun Anlatısı. Pamukkale Üniversitesi Sosyal Bilimler Enstitüsü Dergisi, 37, 161-169.

Sönmez Öz, E. (2015). Annie Ernaux’nun Yapitlarında Toplumsal Cinsiyet. Humanitas, 6, 239-252.

Tilbe, A. (2019). Yeniötesi Yazında Özkurmaca. London: Transnational Press London.

Tondeur, C-L. (1996). Annie Ernaux ou l'Exil Intérieur. Amsterdam, Atlanta GA: Rodopi.

Koşar, Ö. (2020). Güzel Doğulmaz, Güzel Olunur!: Beauvoir'ın Aşkınlık, Irigaray’ın Taklit Düşüncesi Üzerinden Güzellik Sorunsalı. Akdeniz Kadın Çalışmaları ve Toplumsal Cinsiyet Dergisi, 3 (1) , 83-101. 


\section{EXTENDED ABSTRACT IN ENGLISH}

\section{Being women in Annie Ernaux's Simple Passion novel}

In Simple Passion, as in her other novels, the personal events taken turn Ernaux's life are narrated. Simple Passion, carrying stylistically some of the distinctions of postmodern narrative, is a narrative of "I" that offers readers such themes as "alienation to love, becoming a slave to passion, and suffering emotional violence' in a very striking way. The narrative person describes how her forbidden love for an Russian diplomat turned into a sensual passion and delusion; with a very clear simplicity and with the name of the first person in the singular "I" he narrates the fact that this kind of human experience can find everyone, anytime, anywhere, and fearlessly his past and present through a social filter. This sickly state of passion takes over the narrative person's mind, her life, driving her toward spiritual and bodily exhaustion. She also wants to face down the traditional patriarchal perception of women, by entering into a reckoning with her family history, to tell how she got a free female identity from a woman who was subjugated to society. In the study, we will try to examine the passionate captivity of a woman who defies society by trying to exist with her self-identity in a spiral of emotional and sensual violence with a thematic approach. Simple Passion is a novel about a woman who externalizes one of the emotions that today's man lacks most. Concepts such as deprivation of liberty, women's rights and sex discrimination have gained a new dimension with globalization. Currently, the feeling of love seems to have been replaced by sexuality. Emotions are governed like economics; unemployment and poverty cover everywhere. Great ideologies evoke a sense of absence and deprivation in people; a great wave of despair strikes. At such a time, Ernaux explores ways to make life more attractive through literature. The social life and self-life of the author are an integral part of her literary life. In the novel, factuality is highlighted in numerous events connected to reality. Surrounded by society, the writer turns to herself. There is an effort to get rid of some kind of social influence and inner purification. Ernaux is a person who comes out of every experience she has experienced with strength and aims to take on the responsibilities of life according to her choice. She is one of the contemporary writers who best reflects female status with a modest, original and short narrative and best shows that life is a choice. A wounded "I" is the source of their narrative. At the end of the novel, the female narrator, losing A to the other woman, gains peace at sea and in heaven. The sand symbolizes a period of unhappiness and deprivation, and the sea signifies rebirth and reconciliation with its inner life. She returns to the world after the negative experiences she has experienced and creates a new life in reconciliation with her new situation. Her works with social content are produced to mark the differences between social classes and the social injustice between men and women. She is inspired by the essence of life and tries to expose it to the eyes of the reader. Ernaux evaluates literature not as an ordinary aesthetic understanding, but as an exploration of the reality of life and its presentation to the reader. With this approach, she stands against the limitation of the subject in the field of literature, and according to her, every subject should be investigated and written. In this sense, the field of literature and writing is the most appropriate space for self-expression. Simple Passion can be said to be one of the most competent examples of how a violent forbidden love can lead a woman to a helpless and exhausting position.

Keywords: Annie Ernaux; Simple Passion; women; violence; self-life 